\title{
GROWING OLD IN ENGLAND: ECONOMIC AND SOCIAL ISSUES
}

Irene Hardill

Professor of Economic Geography

The Graduate School for Social and Policy Research

The Nottingham Trent University

Burton Street

Nottingham NG1 4BU

Tel: 01158483305

Fax: 01159486385

E-mail: Irene.Hardill@ntu.ac.uk

\section{B Abstract}

This paper examines the economic and social impact of changes in the duration of working life for the 80 per cent of older adults living in urban England. While some people are experiencing extended retirement because of moving out of paid work in their fifties, a growing minority of those beyond the state retirement age continue in paid employment. This paper highlights the considerable challenges for urban policy makers in addressing the economic and social inclusion of all older adults.

\section{B Introduction}

Just over one third of the population of England is aged over fifty years, while men and women aged between 50 years and pensionable age account for almost one in seven of the population (Le Mesurier, 2003, 9). The National Service Framework for 
Older People (DoH, 2001) identifies four distinct groups within those aged over 50 years: those entering old age; those who have completed their paid employment or childrearing; those in a transitional phase within their late 60s and early 70s and those aged 75 and over who are distinguished by an increasing vulnerability to ill health or declining mobility. The above categories attempt to cover two generations and a vast range of experience and skills, and the term 'older adult' therefore covers those who are still of working age ${ }^{1}$, and those of retirement age ${ }^{2}$. In addition, the proportion of older people who are women increases with age because of the longer life expectancy of women relative to men.

In this paper I focus on older adults. i.e., those adults aged over 50 years, as economic restructuring has altered the duration and concept of 'working life' resulting in the transition into retirement undergoing substantial change (Green, 2003; Lawton Smith, 2003). One half of men and one third of women now retire before the state pension age (Disney et al, 1997), for some it is a choice because of the accumulation of assets, including pensions, for others it is the result of economic restructuring, and 'employability’ issues relating to their lack of transferable skills (Campbell, 1999; CRESR, 2002). But men and women also work beyond the state retirement age. A recent study found that overall employment rates for women at age 60 and men at aged 65 stand at 8 per cent and 9 per cent respectively (Smeaton and McKay, 2003). There are a number of reasons for continuing to work beyond the state retirement age, including financial, because of inadequate pension provision, but it is also skill related - their skills and qualifications were still highly valued (ibid).

\footnotetext{
${ }^{1}$ Working age is also called the Second Age.
} 
Some of the key economic and social issues relating to the lived experience of older adults in England's diverse urban areas are highlighted in this paper. Not only are urban areas diverse, but the 'lived experience' of older adults within one town or city varies greatly. Demographic ageing has socio-economic and socio-spatial dimensions because of the ways gender, ethnicity/race, health and wellbeing, ability to live independently, income and social class intertwine to shape the life chances and lived experience of older people in England's urban areas today (Byrne, 1999; Rogers and Power, 2000). Demographic ageing also impacts on the wider urban community, through support ratios, the provision of (public) services, the nature of job opportunities in local labour markets to give three examples. The policy relevance of ageing is both multi-faceted and significant, embracing healthcare, local and regional government, spatial planning, housing, transport, social and economic inclusion and economic development.

The Department for Work and Pensions (DWP) Public Service Agreements (PSAs) targets which took effect in April 2003 recognises the problems older adults have in sustaining paid employment in the last two decades of their working life ${ }^{3}$. While ageism in the labour market is a real barrier to many older adults a few companies have abandoned the notion of a fixed retirement age, and target older workers because they bring maturity, commitment and knowledge. But they are largely in the retail sector, offering part-time jobs (Tempest et al 2002, 475, 484). The average national employment rate for the over 50s during 2001/02 was 69.1 per cent, compared to 75.0 per cent for all working age adults (ONS, 2002), and as Anne Green discusses in this

\footnotetext{
${ }^{2}$ As people reach retirement age they are said to enter the Third Age.

${ }^{3}$ For example under Objective 2, which promotes work as the best form of welfare for people of working age, is concerned with raising the employment rates of disadvantaged areas and groups, including people aged 50 and over.
} 
issue employment rates for older workers do vary in England, with inner city areas and towns in the old industrial heartlands such as Liverpool, Sunderland and Tower Hamlets, recording employment rates of less than 53 per cent), while communities in the M4 valley, including Bracknell Forest and Buckinghamshire have rates over 80 per cent (Green, 2003).

Retirement by 'choice' (upon reaching the statutory retirement age or before) can be characterised by the maintenance of high levels of purchasing power, thanks to occupational pensions and unmortgaged equity in housing, but for increasing numbers they are 'forced' out of the labour market and retirement comes too early, with too little preparation, support and savings (CRESR, 2002, 10). Indeed some move onto sickness or disability benefits (ibid). There is therefore a diversity in the economic circumstances of older adults (ibid, 11), and they remain over-represented in the bottom quintile of the overall net income distribution (Davis et al, 2002). There have been increases in the proportion of pensioners falling into each of the other four quintiles, the result of more receiving income from other sources, such as the 60 per cent of pensioner units who receive income from occupational pensions (ibid, 44). But benefit income remains the most important income source (ibid, 7).

For some people retirement is the catalyst for major lifestyle changes, especially for those with 'grey power' (the resources) to enjoy retirement through leisure and tourism (Tempest et al, 2002) and to make choices in the housing market. While some older adults migrate to rural areas, the majority continues to live in the communities where they have spent most of their lives. Depending on how the terms 'urban' and 
'rural' and ‘older people’ are defined about 80 per cent of older people in England live in urban areas and 20 per cent in rural England (Le Mesurier, 2003, 9). Though there is migration of older people into and within the countryside, especially to favoured places within certain coastal regions, most migration to rural England is done by younger people, thereby disproving the myth that most migrants to rural areas are older retirees moving in from the cities (ibid, 10). Those moving into and out of rural areas tend to be younger, but for some retirement migration could be part of a pre-retirement or early retirement strategy, and so migration may well take place with retirement in mind some years before the state retirement age.

Migration flows do however alter the age structure of sending and receiving communities and the geographical redistribution of the population that has occurred and is still occurring in England brings with it serious cost implications, as to whether communities are shrinking or expanding as their demographic profile changes (Rogers and Power, 2000). Demographic ageing is therefore emerging as a key driver for both urban and regional economic and social development (for a fuller discussion see Brown and Danson, 2003 this issue). After this introduction the paper is structured as follows. Section two focuses on economic and social issues affecting older people in urban areas, and this is followed by an examination of older adult's social capital. The final section is the conclusion.

\section{B Older adults, two speed cities and deprivation}

One important consequence of economic restructuring and the transition to a post industrial social order (for a fuller account see Byrne, 1999, and see above) is one of divided cities, with a polarisation or bifurcation in both the quality of life and the 
economic resources of urban dwellers, including older adults. The wealth gap in cities is often dramatic; the poorest neighbourhoods can be three times as deprived as the city wide average (Rogers and Power, 2000, 49). As the gap between the poorest and the richest pensioners has widened the Department for Work and Pensions (DWP) has a Public Service Agreement (PSAs) that addresses disadvantaged older adults ${ }^{4}$.

In 2000 new indices of deprivation were produced as measures of deprivation for every ward and local authority area in England. It combines a number of indicators which cover six domain scores (income, employment, health deprivation and disability, education skills and training, housing and geographical access to services) based on 33 indicators, into a single deprivation score for each area (DETR, 2000). The 2000 indicators enable a focus on deprivation at a small geographical level, which was not possible with the 1998 index (DETR, 2000, 5) but none of the 33 indicators focus specifically on outcomes for older people.

While it is right that any household with limited material resources should be targeted, the index is constructed to place emphasis on working age households, and those households with young children. For example, the indicator measuring adults on Income Support does not include older people who are eligible but not taking up the benefit (Age Concern, 2000). Moreover employment deprivation focuses on people below state pension age, yet people continue to undertake paid work beyond the current state pension age (ibid). There is perhaps a need for indicators in some of the domains that specifically measure outcomes for older people. This is not only because older people now constitute a significant proportion of the populations of

\footnotetext{
${ }^{4}$ Under Objective 3: combat poverty and promote security and independence in retirement for today’s
} 
deprived and non-deprived communities, but the combination of lower incomes, increasing frailty, isolation, and fear of crime can significantly impact on their ability to access services needed to improve their lives in the community (ibid) ${ }^{5}$.

The most deprived areas, according to the index of deprivation, are predominantly in the big metropolitan districts, some of the London boroughs, large industrial cities in the north and Midlands, some seaside towns and former coalmining areas (DETR, 2000a, 21). For the 88 most deprived local authority districts there is a National Strategy for Neighbourhood Renewal to narrow the gap between outcomes in deprived areas and the rest. The strategy extends beyond infrastructure to tackle social issues, involving residents, the public, private and third sectors (Social Exclusion Unit, 2001). The geography of older adult urban poverty is perhaps somewhat more dispersed than the spatial distribution of poverty as revealed by the index of deprivation. While some older adults are located in the most deprived wards, highlighted by the index, there are others with limited liquid material resources because their assets are tied up in house equity, forming an 'invisible' and spatially diffused component of those older adults living in poverty (see below). Thus while materially and socially excluded older adults are resident in the most deprived urban wards, they are also found in areas beyond these wards.

One important aspect of the quality of life for older adults in urban areas is their housing situation, which can become inextricably linked to health and care. As a

and tomorrow's pensioners, has the target of paying the Pension Credit to at least 3 million pensioner households. Pension Credit will replace the Minimum Income Guarantee in October 2003.

${ }^{5}$ In 1995/6 48 per cent of pensioner households depended on state benefits for at least 75 per cent of their income, and 14 per cent received all their income from state benefits (Hansard, 1998 cited in Bridgwood, 2000), and in 1995/6 1,764,000 people aged 60 and over (single people and couples) were 
result when discussing housing needs we also need to look at them in a broader context of their physical and social environment. A more holistic approach to housing therefore involves an analysis not only of the property but also the neighbourhood/locality as the 'living space', a space which extends beyond the dwelling itself out into the surrounding environment, so consideration of crime, distance from shops, amenities, transport links, cultural amenities and preferences as well as physical aspects of the housing stock and the degree of mobility of elderly people, all profoundly shape older adults' housing needs and feelings. And we should not forget that cold homes - the result of fuel poverty - can exacerbate other ailments such as respiratory and pulmonary diseases among older people.

The vast majority of older adults in urban areas live independently, in their own homes, with an estimated 5 per cent of older households living in sheltered and very sheltered accommodation and 5 per cent living in registered care homes (ODPM, 2001). Around 62 per cent of those in rented accommodation (local authority and social housing) are claiming housing benefit, and the proportion rises with age, with 83 per cent of those aged over 80 (ibid). A greater proportion of households in their 60s and 70s are owner occupiers, including large numbers who bought their accommodation under 'right to buy' in the 1980s.

The housing needs of older people are not homogeneous, increasing numbers now own their homes and many are able to exercise greater choice in housing come retirement. Some older adult owner occupied properties are located in inner city areas that are in a spiral of decline, where the property market has failed. This is especially 
pronounced in parts of the former industrial towns and cities in the north, where long standing elderly residents can feel 'trapped' (Carter, 2003, 14-15). As a policy response in 2002 nine 'pathfinder' renewal areas were set up largely in cities in the Midlands and the north to try and arrest the neighbourhood decline outlined above (ibid).

A substantial amount of capital is locked up in property, an estimated $£ 367$ billion unmortgaged equity, including old properties where the owner cannot afford to carry out much needed repairs. Equity release schemes involve such organisations as the Home Improvement Trust who work with lenders and authorities to expand the equity release market (ibid). The Housing Improvement Agencies play an ‘enabling’ rôle for older people to remain in their own homes, and there may be a need for funding for repairs, improvements, adaptations (stairlifts, downstairs bathrooms) or the provision of support and care services at home.

As older people become frailer, particular housing issues arise because the physical and location characteristics of their home, coupled with the interface with care and support services, which become more important. Surveys reveal that there is a strong preference for living at home with assistance over other options and a preference for sheltered accommodation over living in a nursing home. Effective housing, allied to the right care, support and wider services, such as good transport and community safety, can be the springboard that enables older people to remain involved and live their lives to the full. And new technology, such as community alarm systems, and 
smart homes can play a rôle in enabling older adults live independently (ODPM, 2001).

\section{B Older adults, social capital and community building}

As was noted above most of England's older adults continue to live in urban areas and in the communities where they have a strong sense of belonging. This sense of belonging and commitment to place is 'lived' through such activities as informal neighbouring and care within kin groups, which has traditionally been key to the wellbeing of communities (Young and Wilmott, 1957). Voluntary work, or 'third sector' activity is distinguished by its context from help to the family and wider kin and from informal neighbouring and time giving on a one-to-one basis - sometimes called 'fourth sector' community engagement (Williams, 2003). Both of these may involve the same activities, and be practiced by the same individuals, as volunteering (Beneria, 1999). There is evidence that they are much more prevalent than volunteering for groups likely to face social exclusion including some ethnic minorities (Lukka and Ellis, 2001), older people (Phillipson et al., 1999) and people living in disadvantaged neighbourhoods (Williams, 2003).

The importance of volunteering and its diversity have been highlighted in debates on social capital (DeFilippis, 2001; Williams, 2003). Volunteering is seen by policy makers as an important indicator of social capital (Haezewindt, 2003). As a concept social capital has been around since the 1920s but there has been an explosion of interest in the last decade and it is now one of the most successful exports from sociological theory to everyday life. Bourdieu's classic formulation of social capital was in terms of benefits accruing to individuals and families through participation in 
groups. It is Robert Putnam's (2000) interpretation, however, that has become influential with policy makers. Social capital, according to Putnam, consists of the networks, norms and trust that enable individuals and groups to engage in cooperative activity. Very importantly, in his analysis, social capital yields benefits not only to individuals and families but also nations, cities and neighbourhoods. Increasing community involvement and building social capital are now central themes in debates and policies surrounding the regeneration of areas beset by economic decline.

While rootedness to place can bring with it problems, especially in urban areas where there are economic and social problems and the housing market is failing (see above), older people's longevity in one community may well result in them viewing and experiencing social change rather differently, and indeed older people can provide the 'social glue' that binds communities together (Phillipson et al, 1999). National surveys such as the General Household Survey indicate high levels of contact between older people and their neighbours (Williams, 2003). Those older people who make frequent visits to relatives and friends and who have contact with neighbours are more likely to report good general health, but the proportion aged 75 and over were less likely to do so than the 'younger’ elderly (Bridgwood, 2000, 18).

The relationship between older people and places is perhaps more important in 2003 than ever before due to growing levels of home ownership (Phillipson et al, 1999, 740). A century ago spatial mobility was very much a feature of life as most people working and middle class - lived in private rented accommodation. This was highlighted in Charles Booth’s work in London in the late nineteenth century, the 
working class were 'like fish in a sea', because of frequent relocations within the private rented sector (ibid). The white elderly urban residents interviewed by Phillipson et al (1999) were characterised by a sustained pattern of long term residence, and for many they were the first in their families to achieve such a state (ibid, 740). Home emerged as a site of memories and feelings of 'achievement' were substantial, and they had a sense of belonging to a place, and were aware of a process of demographic change (and renewal) (ibid, 734).

This sense of attachment to place or 'investment' has different layers of complexity, with gender emerging as important. It may help to explain why older women expressed concern about what they saw as deterioration in the community, a crisis in 'public space', with inner city areas being viewed as a threatening environment. This is also linked to older women's physical capacity to deal with the 'hurdles' generated in urban space - broken lifts, litter, cracked pavements, threat of violence, and racist abuse (as experienced by minority ethnic elderly) (ibid). Thus while community is important to older people, they are also acutely aware of changes over time in its meaning and impact on their lives (Phillipson et al, 1999, 733). And the sheer scale of change, especially economic and social decay can leave some older adults feeling trapped, vulnerable and exposed in the very communities that have shaped their lives (Carter, 2003).

Community relationships are still particularly significant in the lives of older women, who, for example, act as ‘neighbourhood keepers’ (Phillipson et al, 1999, 741). Indeed the Urban White Paper (DETR, 2000, 37) noted that women are the backbone of local community life as volunteers as well as mothers, residents and workers. 
Community development efforts often rely heavily on the actions of volunteers and voluntary work can provide individuals, including older adults, with important social contact and social networks. This is particularly important for the large numbers of elderly who live alone. The voluntary sector, community groups, church groups etc. can hold urban communities together despite recent increases in mobility and feelings of individualism. Although retired people remain under represented among volunteers, the 1990s also saw a trend towards more volunteering on their part while participation began to fall away among younger people (Institute for Volunteering Research, 1997).

While communities have changed, the family today is perhaps more fluid now than at any time in modern history, with diverse family patterns and structures, which may have a strong inter-generational spatial dynamic as offspring migrate for work or wellbeing reasons. In the Phillipson et al study (1999) the greater distance between close kin posed difficulties for working class elderly in the context of reliance on public transport. The dissipation of family networks has also been emphasised by Rogers and Power (2002, 41-2) who highlight the sheer scale of urban family breakdown, 'more and more elderly people live alone during the last and most vulnerable years... the loss of stability in families, the isolation of single-person households and the decline of family support - still by far the most valuable and reliable recourse in time of need - leave more and more people vulnerable and exposed'.

\section{B Conclusions}


Life expectancy has increased and the state retirement age has declined but changes have also been occurring in the duration and indeed the concept of 'working life', and as a consequence there is a growing polarisation in the lived experience of the 80 per cent of England's older adults living in urban areas. These economic and social changes have resulted in a blurring of working life and retirement with impacts on material circumstances and quality of life in retirement. For some working life is truncated, while some remain in paid work beyond the state retirement age. There are tremendous quality of life differences experienced by older adults both between and within urban areas because of differences in income levels and economic resources.

As economic circumstances have changed so have the family structures of urban households, for some kin networks have weakened or even dissipated. The dissipation of family networks results in more and more elderly people living alone during their last and most vulnerable years. Social surveys however consistently show that high proportions of residents in deprived areas speak warmly of the quality of the people in their neighbourhoods, suggesting that almost all deprived communities still retain elements of traditionally strong community structures. Much of this is maintained by women, particularly middle aged and elderly women (DETR, 2000, 25). While many older adults have strong feelings about the changing fortunes of their localities in which they had 'invested' much of their lives, and provide the 'social glue' that binds kin networks and communities together.

Demographic ageing presents a series of policy ‘challenges’ for England’s urban areas, and policies need to be in place to: 
- Address the social exclusion of older adults, some of whom live in areas not identified by the index of deprivation;

- Counter the isolation faced by older adults during the last years of their lives, caused by the decline in family support;

- Ensure that the housing stock is appropriate for the needs of older adults.

But demographic ageing also presents ‘opportunities’ for urban regeneration:

- Raising the employment levels of older adults in 'work' in its broadest sense both paid work and unpaid work, such as voluntary work (third and fourth sector);

- Ensure that poorer older adults enjoy the levels of health and wellbeing enjoyed by those older adults with greater material resources;

- Rekindle a sense of community by making greater use of the skills and networks of those older adults who have invested most of their lives in living in one locality - their strong sense of attachment to 'place' could provide roots and the 'social glue’ for communities undergoing restructuring.

\section{B Acknowledgements}

This paper draws on research funded by the Age Concern England and the English Regions Network. I am grateful to Olwyn Ince for her research assistance. The views expressed here are those of the author alone.

\section{References}


AGE CONCERN, 2000: Age Concern's comments on the Office of the Deputy Prime Minister's consultation report 'Updating the English Indices of deprivation', Policy Unit, Age Concern, London.

BENERIA, L. 1999: The enduring debate over unpaid labour, International Labour Review, 138: 287 - 307.

BRIDGWOOD, A. 2000: People aged 65 and over, Office for National Statistics Social Survey Division. Available at http://www.statistics.gov.uk/downloads/theme_social/GHS_People_65_\&_over_v2.p df Accessed on [25 February, 2003].

BROWN, R. and DANSON, M. 2003: 'Going Grey': Demographic Change and the Changing Labour Market in Scotland, Local Economy, 18.4

BYRNE, D. 1999: Social Exclusion, Milton Keynes: Open University Press.

CAMPBELL, N. 1999: The decline of employment among older people in Britain, Centre for the Analysis of Social Exclusion, Paper 19, London: CASE CARTER, H. 2003: The other Kensington, The Guardian, 19.2.2003, 14. CRESR 2002: Hidden Unemployment in the East Midlands Centre for Regional Economic and Social Research, Sheffield Hallam University, September 2002. Available at $<$ http://www.eastmidlandsobservatory.org.uk/loosefiles/hu\%5FHiddenUnempEastMidl andsreport250702finalversion\%2Epdf $>$ Accessed on [25 February, 2003].

DAVIS, I., HARRIS, R. and LEIGH, S. (eds) 2002: Pensioners' Income Series 2000/1. Available at <http://www.dwp.gov.uk/asd/asd6/pi_series_001.pdf $>$ Accessed on [25 February, 2003].

DEFILIPPIS J. 2001: The myth of social capital in community development, Housing Policy Debate, Vol. 12, No. 4,781--806. 
DEPARTMENT OF ENVIRONMENT, TRANSPORT AND THE REGIONS

(DETR) 2000: Our towns and cities: The future delivering an urban renaissance, London:Stationery Office.

DEPARTMENT OF ENVIRONMENT, TRANSPORT AND THE REGIONS (DETR) 2000a: The State of English Cities, London:Stationery Office.

DEPARTMENT OF HEALTH (DoH) 2001 The National Service Framework for Older People: modern standards and service models, London: Department of health DISNEY, R., GRUNDY, E. and JOHNSON, P. 1997: The dynamics of retirement: analyses of the retirement survey, DSS RR42, London: DSS

GREEN, A. E. 2003: Labour Market Trends, Skill Needs and the Ageing of the Workforce: A Challenge for Employability? Local Economy, HAEZEWINDT, P. 2003: Investing in each other and the community: the role of social capital, in C. SUMMERFIELD and P. BABB (eds.) Social Trends, London: Stationery Office, pp $19-26$

INSTITUTE FOR VOLUNTEERING RESEARCH, 1997: National Survey of Volunteering. Available at http://www.ivr.urg.uk/nationalsurvey.htm Accessed on [5 November 2002].

LAWTON SMITH, H. 2003: The labour market potential for scientists, engineers and managers in Milton Keynes, Oxfordshire and Buckinghamshire Local Economy, Le MESURIER, N. 2003 The Hidden store: older people’s contribution to rural communities, London: Age Concern

LUKKA, P. and ELLIS, A. 2001: An exclusive construct? Exploring different cultural concepts of volunteering, Voluntary Action, 3 (3) Available at http://www.ivr.org.uk/culturalconcepts.htm 
OFFICE FOR NATIONAL STATISTICS 2002: Living in Britain 2001. Available at <http://www.statistics.gov.uk/lib2001/index.html> Accessed on [25 February, 2003]. OFFICE OF THE DEPUTY PRIME MINISTER (ODPM), 2001: Quality and Choice for Older People's Housing - A Strategic Framework.

Available at

$<\underline{\text { http://www.housing.odpm.gov.uk/information/hsc/olderpeople/index.htm }>\text { Accessed }}$ [26 February, 2003].

PHILLIPSON, C., BERNARD, M., PHILLIPS, J. and OGG, J. 1999: Older people’s experiences of community life:patterns of neighbouring in three urban areas, The Sociological Review, Vol. 47, No. 4, 715-43.

PUTNAM, R. 2000: Bowling alone: the collapse and revival of American community, New York:Simon and Schuster.

ROGERS, R. AND POWER, A. 2000: A Cities for a small country, London:Faber. SMEATON, D., and McKAY, S. 2003: Working after state pension age: Quantitaive Analysis, Department of Work and Pensions, Research paper no. 182. London: DWP SOCIAL EXCLUSION UNIT, 2001: A new commitment to neighbourhood renewal: National Strategy Action Plan for Neighbourhood Renewal, London:Cabinet Office. TEMPEST, S., BARNATT, C. and COUPLAND, C. 2002: Grey advantage: new strategies for the old, Long Range Planning, Vol 35, 475--92.

WILLIAMS, C. C. 2003: Developing community involvement: contrasting local and regional participatory cultures in Britain and their implications for policy Regional Studies, Vol 37, 5, 531-42

YOUNG, M. and WILMOTT, P. 1957: Family and Kinship in East London, London: Routledge and Kegan Paul. 
